\title{
Gambaran NIHSS pada Pasien Stroke di Ruang Rawat Inap Neurologi RSUP Prof. Dr. R. D. Kandou Manado periode Juli 2014 - Juni 2015
}

\author{
${ }^{1}$ Yunike M. Arisoy \\ ${ }^{2}$ Junita Maja PS \\ ${ }^{2}$ Theresia Runtuwene
}

\author{
${ }^{1}$ Kandidat Skripsi Fakultas Kedokteran Universitas Sam Ratulangi Manado \\ ${ }^{2}$ Bagian Neurologi Fakultas Kedokteran Universitas Sam Ratulangi Manado \\ Email: yunikearisoy@gmail.com
}

\begin{abstract}
Stroke is the interruption of blood flow to the brain that occurs suddenly and persists for more than 24 hours, which can cause disability. NIHSS is a measurement tool assessing the outcomes of stroke. This study aimed to describe NIHSS in stroke patients in the Neurology Departement of Prof. Dr. R. D. Kandou Manado, for the period of July 2014 - June 2015. This is a descriptive retrospective study which used secondary data in the form of inpatients medical record. The result of this study showed that 136 stroke patients who met the criteria used the NIHSS examination with a total of 73 male patients $(53,7 \%)$ and 63 female patients $(46,3 \%)$. The largest age group was $41-65$ years with a total of 96 patients $(70,58 \%)$ and based on the educational level, most patients had high school degree or equivalent as the latest educational level with a total of 66 patients $(48,52 \%)$. NIHSS examination in admitted hemorrhagic stroke patients were 28 patients $(60 \%)$ consisting of 3 patients in the minor category, 16 patients in the moderate category, and 9 patients in the severe category, whereas the discharged patients were 19 patients (40\%), consisting of 6 patients in the normal category, 5 patients in the minor category, 6 patients in the moderate category, and 2 patients in the severe category. NIHSS examination in admitted non-hemorrhagic stroke patients were 45 patients (51\%), consisting of 3 patients in the minor category, 32 patients in the moderate category, and 10 patients in the severe category, whereas discharged patients were 44 patients (49\%) consisting of 6 patients in the normal category, 10 patients in the minor category, 26 patients in the moderate category, and 2 patients in the severe category.
\end{abstract}

Keywords: Stroke Patients, NIHSS Examination

\begin{abstract}
Abstrak: Stroke adalah gangguan aliran darah ke otak yang terjadi mendadak dan bertahan dalam waktu lebih dari 24 jam, yang dapat menimbulkan kecacatan. Pemeriksaan NIHSS merupakan alat ukur yang di gunakan menilai luaran stroke. Penelitian ini bertujuan untuk mengetahui gambaran NIHSS pada pasien stroke di ruang rawat inap Neurologi Prof. Dr. R. D. Kandou Manado, periode Juli 2014 - Juni 2015. Penelitian ini bersifat deskriptif retrospektif dengan memanfaatkan data sekunder berupa catatan rekam medik pasien rawat inap. Hasil penelitian ini didapatkan 136 pasien stroke yang memenuhi kriteria menggunakan pemeriksaan NIHSS dengan jumlah pasien laki-laki sebanyak 73 pasien $(53,7 \%)$ dan perempuan 63 pasien(46,3\%). Kelompok umur terbanyak adalah 41-65 tahun dengan jumlah 96 pasien $(70,58 \%)$ dan kategori pendidikan terakhir paling banyak SMA atau sederajat didapatkan sebanyak 66 pasien $(48,52 \%)$. Pemeriksaan NIHSS pada stroke hemoragik yang masuk sebanyak 28 pasien (60\%) dengan kategori ringan 3 pasien, sedang 16 pasien, dan berat 9 pasien sedangkan pasien keluar sebanyak 19 pasien (40\%) dengan kategori normal 6 pasien, ringan 5 pasien, sedang 6 pasien, dan berat 2 pasien. Pemeriksaan NIHSS pada stroke non hemoragik yang masuk sebanyak 45 pasien (51\%) dengan kategori ringan 3 pasien, sedang 32
\end{abstract}


pasien, dan berat 10 pasien sedangkan pasien keluar sebanyak 44 pasien (49\%) dengan kategori normal 6 pasien, ringan 10 pasien, sedang 26 pasien, dan berat 2 pasien.

Kata kunci : Pasien Stroke, Pemeriksaan NIHSS

Stroke adalah suatu penyakit defisit neurologik akut yang disebabkan oleh gangguan pembuluh darah otak yang terjadi secara mendadak dan menimbulkan gejala dan tanda yang sesuai dengan daerah otak yang terganggu. Stroke juga merupakan salah satu penyebab utama dalam hal kematian,kecacatan maupun beban ekonomi dimasyarakat. ${ }^{1} \quad$ Stroke juga merupakan penyebab kematian ketiga terbanyak di Amerika Serikat. American Heart Association tahun 2009 melaporkan sekitar 795.000 orang di Amerika Serikat terserang stroke setiap tahunnya. ${ }^{2}$ Jumlah penderita stroke di Amerika Serikat tersebut tercatat sebagai serangan stroke pertama sebanyak 610.000 orang, sedangkan 185.000 merupakan stroke yang berulang. Saat ini ada 4 juta orang di Amerika Serikat yang hidup dalam keterbatasan fisik akibat stroke dan 15-30\% diantaranya menderita cacat menetap dan stroke dengan pemulihan total sekitar 460 orang dari 100.000 penderita, $50-70 \%$. $^{3}$ Tahun 2010 stroke merupakan penyebab kematian ke empat di UK setelah kanker, penyakit jantung, dan gangguan pernapasan, dan menyebabkan hampir 50.000 kematian. ${ }^{4}$ Hasil Riskesdas tahun 2013 menunjukkan, prevalensi penyakit stroke di Indonesia meningkat seiring bertambahnya umur. Kasus stroke tertinggi yang terdiagnosis tenaga kesehatan adalah usia 75 tahun keatas $(43,1 \%)$ dan terendah pada kelompok usia 15-24 tahun yaitu sebesar $0,2 \%$. Prevalensi stroke berdasarkan jenis kelamin lebih banyak Laki-laki $(7,1 \%)$ dibandingkan dengan perempuan $(6,8 \%)$. Berdasarkan tempat tinggal, prevalensi stroke di perkotaan lebih tinggi $(8,2 \%)$ dibandingkan dengan daerah pedesaan $(5,7 \%) .^{5}$ Prevalensi kasus stroke tertinggi terdapat di Provinsi Sulawesi Utara $(10,8 \%)$ dan terendah di Provinsi Papua (2,3\%), sedangkan Provinsi Jawa Tengah sebesar $7,7 \%$ prevalensi stroke antara laki-laki dengan perempuan hampir sama. $^{5}$

Penelitian ini bertujuan untuk mengetahui gambaran NIHSS pada pasien stroke di ruang rawat inap RSUP Prof. Dr. R. D. Kandou Manado periode Juli 2014Juni 2015.

\section{METODE PENELITIAN}

Jenis penelitian yang dilakukan ialah deskriptif retrospektif dengan menggunakan data Rekam Medik periode Juli 2014 Juni 2015.

\section{HASIL PENELITIAN}

Hasil yang di dapatkan 136 pasien penderita stroke yang menggunakan pemeriksaan NIHSS.

Gambar 1 memperlihatkan bahwa pasien berjenis kelamin laki-laki lebih banyak dibandingkan perempuan.

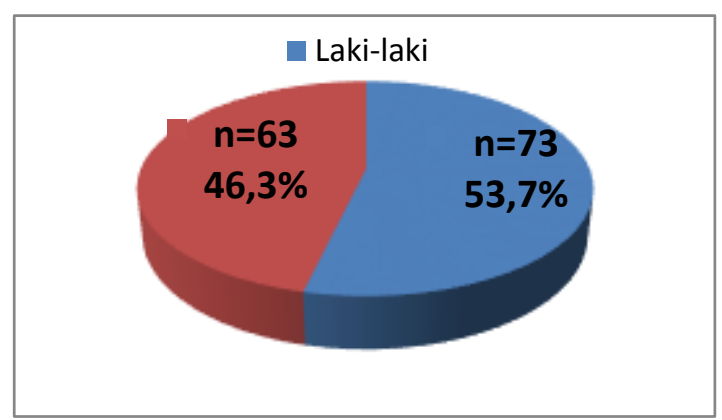

Gambar 1.Karakteristik berdasarkan jenis kelamin pada pasien stroke dengan pemeriksaan NIHSS

Tabel 1. Karakteristik berdasarkan umur pada pasien stroke pada Pemeriksaan NIHSS

\begin{tabular}{ccc}
\hline $\begin{array}{c}\text { Umur } \\
\text { (tahun) }\end{array}$ & $\mathrm{n}$ & $\%$ \\
\hline $12-17$ & 1 & 0,75 \\
$18-40$ & 14 & 10,30 \\
$41-65$ & 96 & 70,58 \\
$>65$ & 25 & 18,40 \\
Jumlah & 136 & 100 \\
\hline
\end{tabular}


Tabel 1 memperlihatkan bahwa penderita stroke terbanyak pada kelompok umur antara 41-65 tahun dengan jumlah 96 pasien $(70,58 \%)$ dan pasien paling sedikit pada kelompok umur 12-17 tahun dengan jumlah 1 pasien $(0,75 \%)$.

Tabel 2 memperlihatkan pendidikan terakhir penderita stroke yang menggunakan pemeriksaan NIHSS terbanyak yaitu SMA $(48,52 \%)$.

Tabel 2. Karakteristik berdasarkan pendidikan pada pasien stroke pada Pemeriksaan NIHSS

\begin{tabular}{ccc}
\hline $\begin{array}{c}\text { Tingkat } \\
\text { pendidikan }\end{array}$ & $\mathrm{N}$ & $\%$ \\
\hline SD & 12 & 8,82 \\
SMP & 16 & 11,76 \\
SMA/sederajat & 66 & 48,52 \\
Diploma & 10 & 7,38 \\
Sarjana & 32 & 23,52 \\
Jumlah & 136 & 100 \\
\hline
\end{tabular}

Hasil yang diperoleh dari pemeriksaan NIHSS berdasarkan stroke hemoragik didapatkan 47 pasien yang terdiri dari pasien normal 6 pasien, stroke ringan 8 pasien, stroke sedang 22 pasien, dan stroke berat 11 pasien (Tabel 3).

Tabel 3. Karakteristik berdasarkan stroke hemoragik dan stroke non-hemoragik pada pasien stroke pada Pemeriksaan NIHSS

\begin{tabular}{cccccc}
\hline Kategori & \multicolumn{5}{c}{ Stroke hemoragik } \\
& N & R & S & B & $\%$ \\
\hline NM & - & 3 & 16 & 9 & 60 \\
NK & 6 & 5 & 6 & 2 & 40 \\
Total & 6 & 8 & 22 & 11 & 100 \\
\hline
\end{tabular}

Keterangan: NM=NIHSS Masuk; NK $=$ NIHSS Keluar; $\mathrm{N}=$ Normal; $\mathrm{R}=$ Ringan; $\mathrm{S}=$ Sedang; $\mathrm{B}=$ Berat

\begin{tabular}{cccccc}
\hline Kategori & \multicolumn{5}{c}{ Stroke non-hemoragik } \\
& N & R & S & B & $\%$ \\
\hline NM & - & 3 & 32 & 10 & 51 \\
NK & 6 & 10 & 26 & 2 & 49 \\
Total & 6 & 13 & 58 & 12 & 100 \\
\hline
\end{tabular}

Keterangan: NM=NIHSS Masuk; NK $=$ NIHSS

Keluar; $\mathrm{N}=$ Normal; $\mathrm{R}=$ Ringan; $\mathrm{S}=$ Sedang; $\mathrm{B}=$ Berat

Pada stroke non-hemoragik atau iskemik didapatkan 89 pasien yang terdiri dari pasien normal 6 pasien, stroke ringan 13 pasien, stroke sedang 58 pasien, dan stroke berat 12 pasien, dan jika ditotalkan menjadi 136 pasien.

\section{BAHASAN}

Stroke merupakan gangguan aliran darah ke otak yang terjadi mendadak dan bertahan dalam waktu lebih dari 24 jam yang dapat menimbulkan kecacatan atau lebih yang menyebabkan kematian, tampa adanya penyebab lain yang jelas selain vaskuler. $^{6}$

Berdasarkan hasil penelitian yang dilakukan dengan pengambilan data dari laporan catatan rekam medis pasien stroke yang menggunakan pemeriksaan NIHSS terdapat sebanyak 136 orang pada periode Juli 2014-Juni 2015.

Hasil yang diperoleh berdasarkan jenis kelamin didapatkan bahwa pasien stroke yang menggunakan pemeriksaan NIHSS lebih banyak pada laki-laki dengan jumlah 73 orang $(53,7 \%)$ sedangkan pada perempuan hanya berjumlah 63 orang (46,3\%). Data di atas sesuai dengan data di bagian Ilmu Penyakit Saraf RSUP dr.Wahidin Sudirohusodo Makassar dari Januari 2000-Desember 2000 dimana stroke lebih banyak pada laki-laki dengan jumlah 57,4\% dibandingkan dengan perempuan $(42,6 \%){ }^{7}$

Data yang diperoleh dari pemeriksaan NIHSS masuk rumah sakit dengan rentang umur 12-17 tahun sejumlah 1 orang $(0,75 \%)$ pasien mengalami stroke ringan, stroke sedang dengan rentang umur 41-65 tahun sebanyak 96 orang $(70,58 \%)$. Hal ini sesuai dengan penelitian yang dilakukan Anderson dkk dalam penelitiannya pada tahun 2001 menyebutkan insiden terbanyak ditemukan pada kelompok umur $>65$ tahun. $^{8}$

Golongan umur pasien stroke dengan pemeriksaan NIHSS dihubungkan dengan hasil pemeriksaan NIHSS, menunjukan bahwa pasien yang berumur 41-65 tahun memberikan gambaran pemeriksaan NIHSS lebih dominan, baik stroke ringan, stroke sedang, maupun stroke berat. ${ }^{9}$ Data yang diperoleh sesuai tingkat pendidikan 
didapatkan pasien stroke yang menggunakan pemeriksaan NIHSS paling banyak adalah SMA yaitu sebanyak 66 orang $(48,52 \%)$. Temuan ini menunjukan bahwa kebanyakan pasien stroke dengan pemeriksaan NIHSS memiliki pendidikan cukup baik sehingga sejalan dengan yang dikemukakan oleh Notoadmodjo bahwa pendidikan pada hakekatnya merupakan usaha untuk membantu individu dalam meningkatkan kemampuan atau perilaku untuk mencapai kesehatan optimal. ${ }^{10}$

Data stroke hemoragik berdasarkan NIHSS masuk didapatkan sebanyak 28 pasien $(60 \%)$ dan NIHSS keluar sebanyak 19 pasien (40\%). Stroke non hemoragik atau iskemik diperoleh NIHSS masuk dengan jumlah 45 pasien (51\%) dan NIHSS keluar dengan jumlah 44 pasien (49\%).

\section{SIMPULAN}

Dari hasil penelitian pada pasien stroke yang menggunakan pemeriksaan NIHSS dapat disimpulkan bahwa pasien stroke terbanyak ialah laki-laki, kelompok umur 41-65 tahun, tingkat pendidikan terakhir SMA/Sederajat, dan hasil pemeriksaan menunjukkan gambaran pemeriksaan NIHSS keluar lebih baik dibandingkan saat masuk.

\section{SARAN}

1. Perlu dilakukan penelitian lebih lanjut mengenai Pemeriksaan NIHSS dengan subjek yang lebih banyak untuk memperoleh hasil yang lebih baik.

2. Rekam medik di RSUP Prof. Dr. R. D. Kandou masih banyak yang perlu di benahi dalam hal registrasi stroke.

\section{DAFTAR PUSTAKA}

1. Misbach J, Rasyid A, Soertidewi L. Pandangan umum mengenai stroke. In: Rasyid A, Soertidewi L, editors. Unit Stroke: Managemen Stroke Secara komprehensif. Jakarta: Balai Penerbit FKUI, 2007; p. 1-17.

2. WHO/SEARO. Surveillance of major noncommunicable disease in South East Asia region. Report of an intercountry consultation. Geneva, 2005.

3. Stroke Facts. Center for Disease Control and Prevention. [cited 2014 Sept 7]. Available from: http://www.cdc.gov/stroke/facts.htm.

4. Stroke Association. Stroke Statistics. [cited 2014 Sept 7]. Available from: http://www.stroke.org.uk/sites/default/fi les/stroke\%20statistics.pdf

5. Badan Litbangkes. Laporan RISKESDAS 2013. Riset Kesehatan Dasar.

6. Kelompok Studi Stroke Perdossi. Guideline Stroke. Jakarta: Perdossi, 2011.

7. Aliah A, Djoenaidi W. Faktor risiko stroke pada beberapa rumah sakit di Makassar periode Januari- September 2000. Jurnal Medika Nusantara. 2004;25:1-5. 2004

8. Anderson CS, Carter KN, Brownlee WJ, Hackett ML, Broad JB, Bonita R. Very long-term outcome after stroke in Auckland, New Zealand. PubMed. 2004;35(8):1920-4.

9. American Stroke Association. Hemorrhagic stroke (Bleeds). 2012 Aug 11. [cited 2013 Oct 31]. Available from: www.strokeassociation.org.

10. Notoadmodjo S. Konsep perilaku dan perilaku kesehatan. In: Pendidikan dan Perilaku Kesehatan. Jakarta: Rineka Cipta, 2003. 